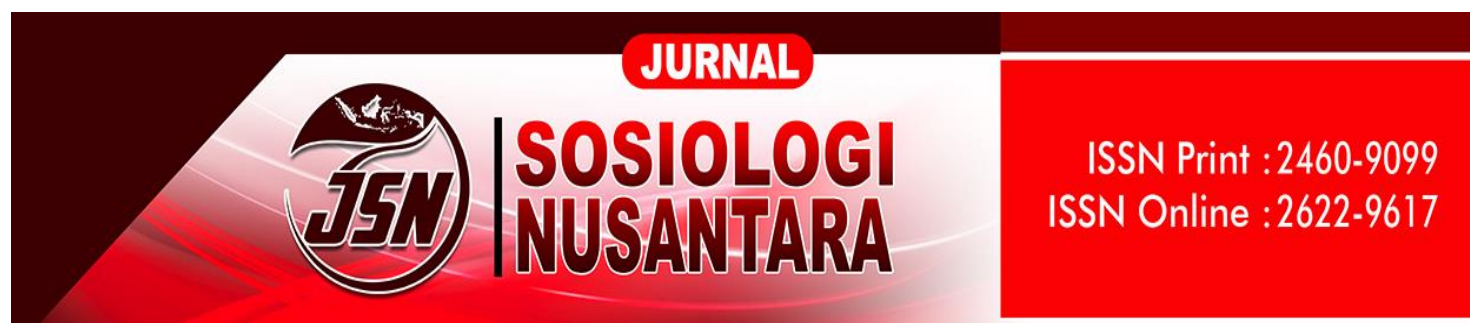

https://ejournal.unib.ac.id/index.php/jsn

DOI ://doi.org/10.33369/jsn.7.2.279-298

\title{
DAMPAK COVID-19 PADA PEDAGANG KAKI LIMA (PKL) DI KOTA SERANG
}

\section{“IMPACT OF COVID 19 ON STREET VENDORS (PKL) IN SERANG CITY”}

\author{
Stevany Afrizal ${ }^{1}$, Putri Tunggal Dewi ${ }^{2}$ \\ stevanyafrizal@untirta.ac.id, tunggald64@gmail.com
}

1,2. Universitas Sultan Ageng Tirtayasa

\begin{abstract}
Abstrak
Pandemi Covid-19 membawa banyak dampak dalam berbagai bidang kehidupan di Negara Indonesia, salah satunya adalah bidang ekonomi. Pada bidang ekonomi terjadinya penurunan pendapatan akibat sedikitnya jual beli yang dirasakan oleh semua golongan pada masyarakat. Tidak terkecuali Pedagang Kaki Lima (PKL) yang termasuk golongan informal juga merasakan dampak dari pandemi ini. Semenjak pemerintah mengeluarkan kebijakan Pembatasan Sosial Berskala Besar (PSBB) hal itu membuat para PKL kehilangan para pembelinya, yang berakibat pada menurunnya pendapatan. Tujuan dari penelitian ini adalah mendeskripsikan dampak covid-19 pada pedagang kaki lima (PKL) di Kota Serang agar bisa tetap bertahan ditengah pandemi covid-19 dan mendeskripsikan peraturan daerah yang mengatur tentang Ketertiban, Kebersihan, dan Keindahan (K3) di Kota Serang. Metode penelitian yang digunakan adalah kualitatif sifatnya deskriptif. Hasil dari penelitian ini adalah (1) Hilangnya pembeli dan pelanggan, karena ketika kebijakan PSBB diterapkan masyarakat lebih memilih untuk tetap di rumah dan enggan untuk keluar rumah jika tidak penting. (2) Menurunnya pendapatan, ini merupakan dampak lanjutan ketika pembeli berkurang, karena secara otomatis itu pun akan mengurangi pendapatannya juga. (3) PKL enggan untuk direlokasi karena takut kehilangan pelanggan dan tempat relokasi yang jauh dari keramaian masyarakat.
\end{abstract}

Kata Kunci: Dampak, Pandemi Covid-19, dan Pedagang Kaki Lima 


\begin{abstract}
The Covid-19 pandemic has brought many impacts in various fields of life in Indonesia, one of which is the economic sector. In the economic field, there is a decrease in income due to at least buying and selling that is felt by all groups in society. Street vendors $(P K L)$ who belong to the informal group also feel the impact of this pandemic. Since the government issued the Large-Scale Social Restriction (PSBB) policy, this has made street vendors lose their buyers, which resulted in a decrease in income. The purpose of this study is to describe the impact of covid-19 on street vendors (PKL) in Serang City so that they can survive during the Covid-19 pandemic and describe local regulations governing Order, Cleanliness, and Beauty (K3) in Serang City. The results of this study are (1) the loss of buyers and customers, because when the PSBB policy is implemented people prefer to stay at home and are reluctant to leave the house if it is not important. (2) Decreased income, this is a follow-up impact when buyers decrease, because it will automatically reduce their income as well. (3) Street vendors are reluctant to be relocated for fear of losing customers and the relocation site is far from the crowds of the community.
\end{abstract}

Keywords: Impact, Covid-19 Pandemic, and Street Vendors

\title{
PENDAHULUAN
}

Pada awal tahun 2020, negara Indonesia dan negara di seluruh dunia mengalami bencana kemanusiaan yang disebut pandemi covid-19, bencana ini membawa dampak yang besar dalam semua lini kehidupan masyarakat, tidak terkecuali pada bidang ekonomi. Terhitung sejak awal tahun 2020 hingga saat ini, bidang ekonomi terus mengalami kekrisisan dan kemerosotan pendapatan yang terjadi secara signifikan. Hal ini tentunya dirasakan oleh semua lapisan golongan masyarakat, tidak hanya golongan menengah ke bawah saja, melainkan golongan atas pun merasakan dampak pandemi covid-19 pada bidang ekonomi ini.

Ketika aktivitas ekonomi tidak berjalan mulus, dikarenakan adanya hambatan dalam memperoleh pendapatan, menyebabkan masyarakat menjadi sulit untuk memenuhi kebutuhan sandang, pangan, dan papan. Akhirnya akan memposisikan mereka pada garis kemiskinan. Untuk bangkit dan keluar dari lingkaran kemiskinan, tentunya masyarakat perlu melakukan usaha-usaha, salah satunya dengan cara melibatkan diri pada pekerjaan sektor informal, yaitu menjadi Pedagang Kaki Lima (PKL). Secara sosiologis pedagang kaki lima merupakan alternatif pekerjaan yang bisa dilakukan oleh semua orang dalam mengatasi pengangguran. Pedagang Kaki Lima (PKL) adalah orang-orang yang bekerja pada sektor informal yang berasal dari masyarakat golongan ekonomi lemah yang biasanya berdagang menempati trotoar- 
trotoar, dan ruang umum, yang merupakan lokasi yang bukan permanen, dan mereka banyak ditemukan di perkotaan (Jamaludin, 2017).

Menurut Widodo (Jamaludin, 2017: 274) menjadi pedagang kaki lima sebenarnya jauh dari kata pekerjaan yang layak, karena penghasilan yang didapatkan tidak besar. Ditambah lagi keberadaan mereka membawa dampak positif dan negatif di lingkungan perkotaan. Sekarang ini dalam masa pandemi covid-19, pedagang harus memiliki strategi bagaimana untuk tetap bertahan disaat pemerintah mengeluarkan kebijakan Pembatasan Sosial Berskala Besar (PSBB) dan masyarakat dihimbau untuk stay at home, yang tentunya mengakibatkan pembeli dibatasi untuk keluar rumah dan hal ini akan berdampak pada menurunnya pendapatan pedagang kaki lima.

Bahkan jauh sebelum adanya covid-19 keberadaan pedagang kaki lima sudah berada dalam posisi terancam. Menurut Widodo (Jamaludin, 2017: 274) mereka berdagang dalam kondisi yang tidak tenang, karena bisa saja sewaktu-waktu usaha yang mereka jalankan mengalami penertiban dan dihentikan oleh pihak yang berwenang. Hal itu dilakukan karena keberadaan Pedagang Kaki Lima (PKL) di tengah kota dianggap masyarakat akan membuat kota terlihat kumuh, kotor dan tidak indah. Untuk merealisasikan kota yang sesuai dengan harapan masyarakat yaitu kota yang bersih, indah, dan tertata, maka pemerintah daerah mengeluarkan Peraturan Daerah No. 10 Tahun 2010 tentang Ketertiban, Kebersihan, dan Keindahan (K3).

Seperti halnya, Pasar Lama Kota Serang yang merupakan merupakan pasar tradisional. Pasar ini terletak di jalan Maulana Hasanudin No. 30, Kotabaru, Kecamatan Serang. Daerah ini sangat ramai dikunjungi oleh masyarakat Kota Serang karena berdekatan dengan pusat kota yaitu Alun-Alun Kota Serang, dan fasilitas umum yaitu stasiun kereta Kota Serang. Ramainya daerah ini dimanfaatkan oleh para Pedagang Kaki Lima (PKL) untuk mendirikan lapaknya, atau hanya sekedar sebagai tempat singgah berjualan beberapa jam, sebelum ke tempat berdagang selanjutnya.

Para Pedagang Kaki Lima (PKL) di sepanjang jalan Pasar Lama menawarkan barang dagangan yang beragam berupa makanan yang tidak diproses, seperti: ikan segar, kelapa muda, snack, ada juga makanan siap saji atau sudah diproses, seperti: dimsum, telur gulung, pecel lele, selendang mayang. 
Tabel 1. Data Jumlah Pedagang Kaki Lima Pasar Lama Kota Serang

\begin{tabular}{llc}
\hline No & \multicolumn{3}{c}{ Pedagang Berdasarkan Jenis Dagangan } & Jumlah \\
\hline \multicolumn{4}{l}{$\begin{array}{l}\text { Makanan tidak diproses (Pedagang asongan, pedagang } \\
\text { buah-buahan: duren, pisang, kelapa, jeruk, dan } \\
\text { pedagang ikan) }\end{array}$} & 22 \\
\hline $\begin{array}{l}\text { Makanan siap saji (Pedagang makanan berat: baso, nasi } \\
\text { jamblang, nasi goreng, nasi bakar sumsum, pecel lele, } \\
\text { bubur ayam, dan nasi uduk, Sedangkan pedagang } \\
\text { makanan ringan: dimsum, cilor, siomay, selendang } \\
\text { mayang, martabak, kue cubit, pastel, gorengan, lumpia }\end{array}$ & 26 \\
\hline $\begin{array}{l}\text { mataram, street food, pempek, dan pancong) } \\
\text { Barang bukan makanan (Bungga-bungga, kaca, dan } \\
\text { Jepatu) }\end{array}$ & 13 \\
\hline
\end{tabular}

Di masa pandemi covid-19, kebertahanan Pedagang Kaki Lima (PKL) di Pasar lama berpengaruh terhadap jual beli masyarakat, dikarenakan munculnya berbagai tantangan baru di era sekarang. Salah satunya adalah perilaku masyarakat berbelanja secara online di masa pandemi ini. Dan juga adanya kebijakan Pembatasan Sosial Berskala Besar (PSBB) dengan menghindari interaksi secara langsung untuk memutus penyebaran covid-19. Sehingga Pedagang Kaki Lima mengalami penurunan pendapatan, kerugian bahkan sampai gulung tikar.

Selanjutnya Peraturan Daerah (PERDA) Kota Serang No. 10 Tahun 2010, tentang Ketertiban, Kebersihan, dan Keindahan (K3). Hal ini menimbulkan masalah baru bagi pemerintah terhadap kehadiran pedagang kaki lima di Kota Serang. Hal ini disebabkan mereka berjualan di trotoar jalan sehingga dapat mengganggu pengguna jalan kaki, menyebabkan kemacetan lalu lintas dan mengurangi keindahan kota.

Dengan adanya fenomena tersebut, penting kiranya diteliti lebih dalam mengenai Dampak Covid-19 Pada Pedagang Kaki Lima di Kota Serang dengan rumusan masalah penelitian sebagai berikut:

1. Bagaimana dampak covid 19 pada pedagang kaki lima (PKL) di Kota Serang agar bisa tetap bertahan ditengah pandemi covid-19?

2. Bagaimana kebijakan peraturan daerah tentang penataan pedagang kaki lima terhadap pedagang yang berada di Pasar Lama Kota Serang? 
Munculnya tantangan baru yang dirasakan oleh pedagang kaki lima di Pasar Lama pada masa covid-19 ini, tidak membuat mereka menyerah akan keadaan. Dalam realitanya masih terlihat adanya pedagang kaki lima di Pasar Lama. Dari latar belakang masalah yang telah diutarakan diatas, maka tujuan dan manfaat dari penelitian ini adalah (1) mendeskripsikan dampak covid 19 pada pedagang kaki lima (PKL) di Kota Serang agar bisa tetap bertahan ditengah pandemi covid-19 dan (2) dapat dijadikan bahan pertimbangan atau masukan ketika merumuskan kebijakan dan peraturan daerah mengenai pedagang kaki lima khususnya di Kota Serang.

\section{METODE PENELITIAN}

Metode penelitian yang digunakan adalah kualitatif yang bersifat deskriptif. Yang bertujuan untuk mendeskripsikan eksistensi pedagang kaki lima di wilayah perkotaan pada masa pandemi covid-19. Dengan teknik pengumpulan data melalui pengamatan langsung terhadap objek penelitian, dan wawancara mendalam terhadap subjek penelitian yang dilakukan secara random sampling. Yang dimaksud random sampling adalah pengambilan sampel dari populasi yang dilakukan secara acak tanpa memperhatikan strata yang ada dalam populasi tersebut (Sugiyono, 2010). Penganalisisan data dilakukan sejak proses penelitian, hingga penarikan kesimpulan ketika yang telah didapat dianggap sudah mampu menjawab permasalahan penelitian. Setelah data penelitian dianalisis, selanjutnya hasil penelitian disusun mengikuti prosedur penulisan kualitatif, menjadi bentuk paragraf-paragraf, bukan berbentuk angka.

Lokasi penelitian ini terletak di Pasar Lama Kota Serang, yang termasuk daerah yang cukup ramai dan sering dikunjungi oleh masyarakat Kota Serang maupun masyarakat luar Kota Serang. Dalam penelitian ini, memiliki 3 fokus subjek penelitian, diantaranya: 5 orang pedagang kaki lima (PKL) illegal yaitu Fauzi, Yunus, Muklas, Ahmad, dan Andrew, 1 orang satpol pp yaitu Hasanudin, dan 3 orang pembeli yaitu Eri, Nur Maulida, dan Hidayanti. Namun, agar dapat memperkaya hasil penelitian, untuk sumber data penulis bukan hanya menggunakan sumber primer saja, melainkan mengaitkan juga dengan sumber sekunder. 


\section{PEMBAHASAN}

\section{Latar Belakang Hadirnya Pedagang Kaki Lima (PKL) di Pasar Lama}

Pedagang Kaki Lima (PKL) merupakan orang yang berada pada golongan ekonomi menengah kebawah, yang memiliki usaha namun pada tempat yang tidak seharusnya, misalnya di bahu jalan, trotoar, ataupun taman kota.

Gambar 1. Penggunaan Trotoar oleh PKL di Pasar Lama

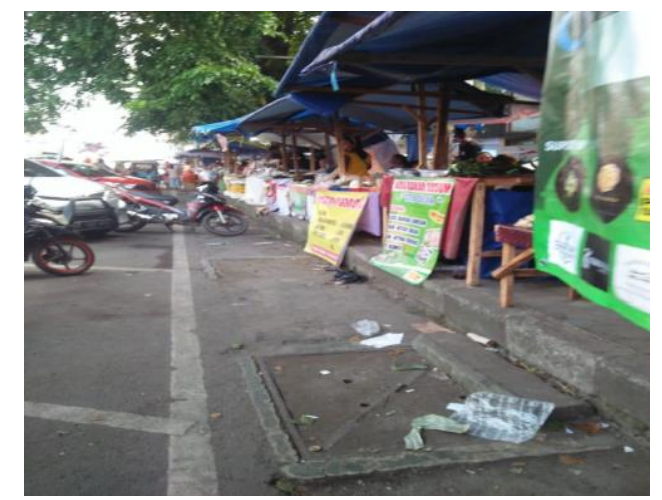

Sumber : Dokumentasi Peneliti, 2021

Begitupun dengan pedagang kaki lima di Pasar Lama, mereka berjualan dan mendirikan lapak di bahu jalan dan trotoar sepanjang jalan Maulana Hasanudin No. 30, Kotabaru, Kecamatan Serang. Para pedagang kaki lima di Pasar Lama menawarkan berbagai jenis kebutuhan masyarakat, mulai dari kebutuhan sandang, sampai pada kebutuhan pangan. Contohnya: perabotan rumah tangga, hiasan dinding, sepatu, baju, lauk pauk mentah, es kelapa muda, dan jajanan ringan seperti dimsum, cilor, selendang mayang, dan lainnya. Para pedagang yang berdagang di Pasar Lama, bukan hanya warga yang berdomisili Kota Baru dan sekitarnya saja, tetapi banyak juga para pedagang yang rantauan dari luar kota, seperti Tangerang, Merak, dan Lampung.

Saat ini Pasar Lama semakin beragamnya para pedagangnya yang terdiri dari berbagai domisili yang berbeda. Sebelum menjadi seperti sekarang ini, ternyata hadirnya pedagang kaki lima di Pasar Lama memiliki cerita di zaman dahulunya, dimana dahulunya daerah tersebut merupakan daerah yang sangat ramai, orang Serang menganggap daerah tersebut merupakan mall Kota Serang, hiburan seperti bioskop, kegiatan jual beli ada di daerah tersebut, tepatnya di daerah Pasar Lama sampai ke Royal. Namun, berjalannya waktu, mall modern hadir ditengah masyarakat, dengan menawarkan segala produk kebutuhan masyarakat, pada tempat yang jauh lebih nyaman. Hal itu membuat minat berbelanja masyarakat dalam pemenuhan kebutuhan 
menjadi berubah, yang awalnya masyarakat Kota Serang akan menjadikan Pasar Lama sebagai tujuan untuk pemenuhan kebutuhan, namun saat ini berubah, masyarakat akan datang ke mall modern, seperti, Ramayana, Borobudur, Mall Of Serang (MOS).

Dengan adanya perubahan tersebut, membuat daerah Pasar Lama menjadi lebih sepi dibandingkan sebelum adanya mall modern. Hal itu membuat para pedagang yang ada di dalam Pasar Lama merasa tersingkir dan kehilangan para pelanggannya, tetapi mereka mencoba untuk tetap bertahan dan mencari para pelanggan dengan cara memajukan lapak daganganya ke bahu jalan di luar pasar, bukan lagi di dalam pasar. Dengan tujuan mempermudah para pelanggan untuk membeli karena tidak perlu lagi masuk ke dalam pasar dan dengan itu juga membuat barang dagangan banyak dilirik orang yang berlalu lalang di luar pasar.

"Para pedagang di Pasar Lama merasa tersingkir karena adanya mall elit, nah disitulah mulai, satu pedagang maju kedepan, pedagang yang lain juga ngikutin, karena ngerasa pembeli itu ga mau masuk ke dalam pasar" (Wawancara dengan informan Hasanudin, 20 April 2021).

Dengan latar belakang awal yang menyebabkan Pedagang Kaki Lima (PKL) hadir di Pasar Lama, menyebabkan hadirnya pedagang kaki lima lain, yang bahkan berasal dari luar Kota Serang. Selain latar belakang awal, terdapat juga beberapa faktor yang mendorong semakin maraknya pedagang kaki lima hadir di daerah Pasar Lama, diantaranya: Pertama, pendidikan yang rendah, masih rendahnya tingkat pendidikan di Kota Serang, membuat masyarakat Kota Serang tidak mampu untuk bersaing dalam pekerjaan sektor formal, karena adanya keterbatasan pada ijazah pendidikan terakhir, akhirnya masyarakat akan menjadikan sektor informal sebagai tujuan untuk mendapatkan pekerjaan, yaitu dengan menjadi Pedagang Kaki Lima (PKL). Karena, untuk menjadi pedagang kaki lima tidak memerlukan pendidikan formal yang tinggi, biasanya mereka akan berpegang pada pengalaman yang didapat selama bekerja saja. Semakin lamanya seseorang berdagang, semakin bertambahlah pengalaman mereka, hal tersebut sebagai modal pengetahuan dalam berusaha (Musahwi, Stevany Afrizal, 2018). Berdasarkan wawancara yang telah dilakukan oleh peneliti, dari 5 orang pedagang kaki lima, 3 orang pedagang hanya mengenyam pendidikan pada tingkat Sekolah Dasar (SD), 1 pada tingkat Sekolah Menengah Atas (SMA), dan 1 sedang proses pada tingkat Perguruan Tinggi namun mengalami cuti. 
Kedua, culture masyarakat yang tidak bisa bekerja dalam tekanan. Masyarakat Indonesia cenderung memilih hidup dengan santai, bebas, dan tidak dalam tekanan, jika bekerja pada sektor formal tidak akan jauh dari target, yang akan menuntut para pekerja agar dapat mencapai target tersebut. Hal itu berbanding terbalik dengan culture masyarakat, maka dari itu kebanyakan masyarakat akan memilih sektor pekerjaan yang santai, dan tidak dalam tekanan.

Pedagang kaki lima sebagai usaha milik sendiri yang lebih dikenal dengan pola kegiatannya yang santai, tidak teratur dan bebas, baik dari waktu buka dan tutup, pendapatan, maupun barang dagangan yang dijajakan, dijadikan sebagai tujuan bagi mereka yang ingin bekerja dengan santai, bebas, dan tidak dalam tekanan orang lain (Andriani \& Marlina, 2020).

"Enaknya berdagang gini mah kan penghasilannya per harinya ada aja.. Tidak harus berdagang setiap hari juga, kalau mau libur, tinggal libur" (Wawancara dengan Informan Fauzi, 1 April 2021). "Kalau bekerja di perusahaan saya ga mau, yang enak mah enak, yang kabur mah kabur" (Wawancara dengan Informan Yunus, 3 April 2021).

Ketiga, keterbatasan ekonomi. Golongan kelas menengah ke bawah adalah golongan kelas yang mayoritas ada di Indonesia, dibandingkan dengan golongan kelas menengah ke atas. Kesulitan akan ekonomi ini membuat masyarakat memiliki keterbatasan dalam memperoleh pekerjaan yang memerlukan modal yang sangat besar. Akhirnya masyarakat akan mencari pekerjaan yang hanya memerlukan modal yang sedikit, karena adanya keterbatasan ekonomi ini, Pedagang Kaki Lima (PKL) lah jawaban yang bisa dilakukan untuk tetap memperoleh pendapatan di tengah keterbatasan ekonomi mereka.

Menjadi pedagang kaki lima hanya memerlukan modal yang kecil, misalnya dari sisi tempat berdagang, mereka tidak perlu mengeluarkan biaya untuk menyewa ruko dengan harga yang tinggi, karena mereka hanya menempati lahan-lahan umum. Biaya sewa lahan para Pedagang Kaki Lima (PKL) di Pasar Lama terbagi menjadi 2 (dua), yaitu biaya awal, dan biaya harian. Untuk biaya awal dikenakan biaya sewa yang cukup mahal, kisaran 3.000.000 sampai 12.000.000, namun untuk selamanya dan untuk biaya harian, dikenakan biaya dengan nominal kecil dan bahkan seikhlasnya.

"Ini bayar, ke yang punya SK parkir, yang punya SK parkirnya kan izin ke dishub, kita bayar sekitar 12.000.000, tapi itu untuk selamanya” (Wawancara dengan Informan Andrew, 19 April 2021). "Ini kalau awal jualan bayar lapaknya 
sampai 3.000.000, walaupun ga ada bangunan, cuma lapak doang. Nanti bayarnya ke yang jaga parkiran" (Wawancara dengan Informan Muklas, 3 April 2021). "Untuk harian ada pungutan 2.000, kalau mau ngasih ya ngasih kalau ga, ya ga ngasih. Ngasihnya itu ada yang minta (tukang parkir)" (Wawancara dengan Informan Andrew, 1 April 2021).

\section{Peraturan Daerah dan Pedagang Kaki Lima (PKL)}

Hadirnya pedagang kaki lima di tengah masyarakat banyak memunculkan masalah sosial pada masyarakat, terutama terkait tata ruang kota yang terlihat gagal karena adanya penyalahgunaan fasilitas umum oleh para pedagang kaki lima. Maka dari itu, untuk menangani hal tersebut pemerintah daerah mengeluarkan kebijakan berupa Peraturan Daerah (PERDA) Kota Serang No. 10 Tahun 2010, tentang Ketertiban, Kebersihan, dan Keindahan (K3). Penjelasan tentang pedagang kaki lima dalam perda tersebut disinggung pada: (1) pasal 29 huruf a yang berbunyi "Dilarang mempergunakan ruang milik jalan selain peruntukan jalan umum" (2) pasal 29 huruf d yang berbunyi "Dilarang berusaha atau berdagang di trotoar, jalan atau badan jalan, taman jalur hijau yang bukan peruntukannya" (3) pasal 29 huruf k yang berbunyi "Dilarang mendirikan kios dan berjualan di trotoar, taman, jalur hijau atau dengan cara apapun yang dapat mengakibatkan kerusakan kelengkapan taman, bunga, atau taman lainnya.

Untuk mendukung peraturan tersebut, agar para pedagang kaki lima tidak lagi menyebar pada setiap titik dikota-kota dan menggunakan fasilitas umum yang ada, Dinas Perdagangan, Perindustrian dan Koperasi (disperindagkop) Kota Serang, melakukan penetapan daerah yang diizinkan untuk mendirikan lapak pedagang kaki lima, yang hasilnya berupa Surat Keputusan atau SK Walikota. Adapun 7 daerah yang diizinkan untuk melakukan usaha para Pedagang Kaki Lima (PKL) di Kota Serang, diantaranya: Pasar Kalodran, Pasar Rau, Pasar Kepandean, Pasar Royal, Serang Plaza atau Ramayana Serang, Kawasan Banten Lama, dan Taman Sari. Pasar Lama yang merupakan tempat yang dijadikan sebagai objek penelitian, tidak termasuk kedalam daerah yang diperbolehkan untuk melakukan usaha Pedagang Kaki Lima (PKL). Maka dari itu sering terjadinya penertiban dan penjaringan pedagang kaki lima oleh satpol pp di lokasi tersebut. 
Tabel 2. Rekapitulasi Pelanggaran K3 yang Teridentifikasi oleh Satpol PP

\begin{tabular}{ccccc}
\hline No & Tanggal & Lokasi & $\begin{array}{c}\text { Jenis } \\
\text { Kegiatan }\end{array}$ & $\begin{array}{c}\text { Jumlah } \\
\text { Pelanggar }\end{array}$ \\
\hline 1 & 1-Apr-2021 & Pakupatan & PKL & 33 \\
\hline 2 & 5 -Apr-2021 & Pasar Rau & PKL & 52 \\
\hline 3 & 6-Apr-2021 & Stadion Maulana & PKL & 30 \\
& & Yusuf & \\
\hline 4 & 8-Apr-2021 & Kepandean & PKL & 28 \\
\hline 5 & 10-Apr-2021 & Pasarlama & PKL & 32 \\
\hline & & Jumlah & $\mathbf{1 7 5}$ \\
\hline
\end{tabular}

Sumber : Satuan Polisi Pamong Praja (Satpol pp) Kota Serang

Penertiban dan penjaringan pedagang kaki lima di Kota Serang oleh Satpol PP sebagai lembaga eksekutor dalam penerapan peraturan daerah, dilakukan pada hari Selasa dan Kamis, pukul 07.00-16.00 WIB, selain itu pun bisa saja tetap dilakukan penertiban, ketika mendapatkan perintah dari Walikota, ataupun dinas terkait, tidak terkecuali juga ketika masuknya aduan masyarakat setempat kepada satpol PP Kota Serang. Aduan masyarakat tentang Pedagang Kaki Lima (PKL) ini dikarenakan adanya anggapan masyarakat bahwa hadirnya pedagang kaki lima akan membuat kota menjadi kotor, kumuh, dan tidak tertib.

Gambar 2. Penertiban PKL di Pasar Lama oleh Satpol PP Kota Serang

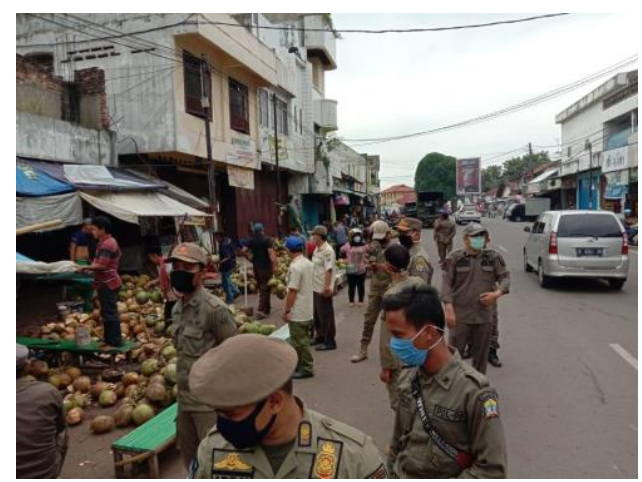

Sumber : Dokumentasi pada halaman web Satpol PP Kota serang, (satpol

pp.serangkota.go.id, 2020)

Peraturan daerah tersebut ada agar ditaati oleh para Pedagang Kaki Lima (PKL), untuk tidak lagi berjualan dan berdagang, serta tidak lagi mendirikan kios baik permanen ataupun semi permanen pada bahu jalan, trotoar, dan tempat yang bukan 
seharusnya. Karena jika tetap melanggar, pedagang sewaktu-waktu bisa saja terjaring razia, saat sedang dilakukannya penertiban oleh satpol pp. Penertiban itu dilakukan dengan cara melakukan penyitaan barang dagangan, yang akan ditahan selama 3 hari, lalu adanya perjanjian untuk tidak lagi melakukan kesalahan tersebut, ditandatangani oleh pedagang kaki lima yang bersangkutan. Dalam proses penyitaan terdapat mekanismenya, seperti yang dipaparkan oleh Hasanudin selaku informan dari pihak satpol pp:

"Pertama, dikasih surat teguran selama 7 hari. Surat teguran kedua itu selama 3 hari. Nanti kalau masih ngeyel ada surat teguran ketiga, selama 3 hari. Jadi jangka waktu untuk pkl pindah dari situ, karena itu area sudah melanggar, itu 13 hari. Kalau masih menentang dan ngeyel, baru kita usir. Kalau masih gak mau di usir dari situ, kita sita dulu barangnya" (Wawancara dengan Informan, 20 April 2021).

Selain penyitaan barang dagangan, terdapat juga sanksi dan denda, yang telah diatur dalam Peraturan Daerah (PERDA) Kota Serang No. 10 Tahun 2010 pasal 39, bahwa "Dikenakan sanksi dan denda sebesar Rp. 100.000,00 (seratus ribu rupiah) untuk orang yang berusaha atau berdagang, dan juga yang mendirikan kios, di trotoar, jalan atau badan jalan, taman jalur hijau, dan tempat lain yang bukan peruntukannya”. Hal ini sesuai penerapannya di lapangan, karena berdasarkan paparan Fauzi:

"Kalau kejaring itu nanti dikasih peringatan dan penjelasan gimana-gimananya biar enak, terus ada denda 100.000 biar bisa keluar lagi" (Wawancara dengan Informan, 1 April 2021).

Walaupun sudah terdapat sanksi dan denda jika melanggar peraturan yang telah dibuat, namun tetap saja para pedagang kaki lima membandel untuk kembali berjualan dan mendirikan lapak di Pasar Lama. Pemberdayaan Pedagang Kaki Lima (PKL) sebagai cara selanjutnya yang bisa diterapkan. Karena Menurut Jamaludin (2017) kehadiran pkl jika dikelola dengan baik, akan menjadi aset ekonomi bangsa Indonesia, yang memberi andil besar dalam ketenagakerjaan, pengentasan kemiskinan, dan menjadi kutup pengaman ekonomi kerakyatan. Hadirnya pedagang kaki lima juga dapat menekan angka pengangguran, dan dapat membantu masyarakat dalam pemenuhan kebutuhan dengan harga yang terjangkau. Adanya pkl di tengah kota menjadi kontroversial, karena memberikan dampak positif, dan pada sisi lain akan memberikan dampak negatif. Maka dari itu pkl di tengah kota tidak bisa benar-benar dimusnahkan 
dan dihilangkan, diperlukannya sistem yang baik untuk mampu menata dan memberdayakan pkl, agar dapat menjadi aset ekonomi tanpa membawa dampak negatif.

Untuk penataan dan pemberdayaan pkl, diatur dalam Peraturan Daerah (PERDA) Kota Serang Nomor 4 Tahun 2014. Seperti yang terdapat dalam perda tersebut, sebelum dilakukan pemberdayaan, perlu adanya penataan terlebih dahulu untuk pedagang kaki lima, penataan tersebut tertuang dalam peraturan daerah Kota Serang No 4 Tahun 2014 pasal 4 ayat 2, yang berbunyi "Penataan PKL sebagaimana yang dimaksud pada ayat (1) dilakukan dengan cara: pendataan PKL, pendaftaran PKL, penempatan dan pemindahan PKL, penetapan lokasi dan penghapusan lokasi PKL, dan peremajaan lokasi PKL”.

Setelah tahap penataan dilakukan, data mengenai Pedagang Kaki Lima (PKL) beserta Tempat Kegiatan Usaha (TKU) masuk dalam pendataan Dinas Perdagangan, Perindustrian, dan Koperasi Kota Serang, barulah tahap selanjutnya dilakukannya pemberdayaan terhadap pedagang kaki lima. Terkait pemberdayaan tersebut tertuang dalam peraturan daerah Kota Serang No 4 Tahun 2014 pasal 4 ayat 3, yang berbunyi "Pemberdayaan PKL sebagaimana yang dimaksud pada ayat (1) meliputi: peningkatan kemampuan berusaha, fasilitasi akses permodalan, fasilitasi bantuan sarana dagang, penguatan kelembagaan, fasilitasi peningkatan produksi, pengelolaan, pengembangan jaringan \& promosi, dan pembinaan \& bimbingan teknis".

Peraturan daerah No 4 Tahun 2014 tepatnya pasal 4 ini membicarakan terkait pendataan PKL, yang pada akhirnya akan bermuara pada solusi relokasi para pedagang kaki lima pada lokasi yang telah ditetapkan. Setelah terdata maka para pedagang tersebut akan memperoleh berbagai bantuan dari pihak terkait, berupa fasilitas, baik pembinaan, sosialisasi, bahkan sarana dagang. Untuk pengrelokasian para Pedagang Kaki Lima (PKL) Kota Serang, pemerintah bekerjasama dengan dinas terkait telah menyediakan tempat pusat relokasi di Pasar Kepandean Kota Serang. Namun, dalam pelaksanaannya kebanyakan para pedagang kaki lima menolak untuk direlokasi ke tempat yang telah disediakan, dan lebih memilih untuk tetap berdagang di trotoar atau bahu jalan. Tidak terkecuali dengan pedagang kaki lima di daerah Pasar Lama, mereka juga enggan untuk direlokasi, berdasarkan temuan dilapangan yang diperoleh dari hasil wawancara dengan 5 pedagang kaki lima di Pasar Lama menjelaskan bahwa, alasan mereka enggan untuk direlokasi ke Pasar Kepandean, diantaranya karena: (1) hilangnya 
pelanggan dan sulitnya untuk mencari kembali pelanggan baru di tempat yang baru (2) tempat relokasi jauh dari pusat kota dan jauh dari keramaian (3) tempat tidak nyaman.

Hal tersebut memunculkan masalah baru dalam pelaksanaannya, dalam satu sisi pemerintah telah mengeluarkan biaya untuk penanganan Pedagang Kaki Lima (PKL) di Kota Serang dengan membangun lokasi Tempat Kegiatan Usaha (TKU), namun dalam sisi lain tempat tersebut tidak sesuai dengan yang diharapkan para pedagang. Hal tersebut juga dikeluhkan oleh satpol PP:

"Kita pas itu beberapa kali menertibkan, dan arahan pak walikota itu disuruh di relokasi ke Pasar Kepandean, tapi ternyata balik lagi pedagangnya. Pemerintah udah menyediakan tempat, bekerjasama disperindagkop juga, tapi pkl nya gamau. Padahal digratiskan” (Wawancara dengan Informan Hasanudin, 20 April 2021).

Semakin banyaknya pedagang kaki lima, masih menjadi fenomena yang disoroti oleh pemerintah dan masyarakat, fenomena tersebut masih belum bisa dikendalikan, padahal pemerintah dan dinas terkait telah membuat berbagai kebijakan, peraturan, dan tentunya solusi. Sekarang muncul pertanyaan, apakah kebijakan, peraturan, dan solusi yang ditawarkan oleh pemerintah sudah efektif dan sesuai dengan harapan para pedagang kaki lima? Berdasarkan temuan dilapangan dari hasil wawancara dengan 5 orang pedagang kaki lima di Pasar Lama, menjelaskan bahwa adanya peraturan pemerintah, yang akan berakhir pada tahap penertiban, dikatakan efektif. Karena, sebelum adanya penertiban satpol pp sebagai eksekutor dari peraturan daerah melakukan sosialisasi dan peringatan terlebih dahulu pada daerah yang akan dilakukan penertiban, peringatannya berupa perintah untuk membersihkan daerah tersebut pada tanggal sekian sampai sekian, dan diharapkan untuk tidak berdagang pada daerah tersebut, ditanggal yang telah ditentukan.

"Bener sih sebenarnya cara yang dilakukan pemerintah itu, karena kan sebelumnya juga udah dikasih tau, kitanya juga udah siap-siap kan" (Wawancara dengan Informan Muklas selaku PKL, 4 April 2021).

Berdasarkan sudut pandang informan lain yaitu 1 orang satpol pp dan 3 orang pembeli pun mengatakan bahwa adanya peraturan daerah tersebut dinilai efektif dalam merealisasikan K3 (ketertiban, kebersihan, dan keindahan). Namun, dikatakan efektif ketika adanya kerjasama antar berbagai pihak, dengan mengambil perannya masingmasing, diantaranya: 
a) Pemerintah, membuat dan mengeluarkan peraturan dan kebijakan yang sesuai dengan harapan dan kondisi pedagang kaki lima.

b) Masyarakat, untuk mengamati dan memberikan aduan kepada pihak terkait jika ada pelanggaran-pelanggaran.

c) Satpol pp, sebagai eksekutor dalam penerapan peraturan yang telah ditetapkan, dilakukan dengan transparan dan persuasif.

d) PKL, mentaati himbauan, peringatan, dan peraturan yang telah dikeluarkan oleh pemerintah, hal ini juga untuk kesejahteraan dan ketentraman bersama.

\section{Dampak Pandemi Covid-19 pada Pedagang Kaki Lima di Kota Serang}

Virus corona atau disebut juga dengan Severe Acute Respiratory Syndrome Coronavirus 2 (SARS-CoV-2), merupakan virus baru yang menyerang imun dan pernafasan, virus ini hadir pertama kali di Wuhan, China pada akhir tahun 2019 dan semakin menyebar keseluruh dunia. Tidak terkecuali Indonesia, yang kasus pertamanya ditemukan pada 2 Maret 2020. Hadirnya virus covid-19 di Indonesia menyebabkan terjadinya guncangan dalam tatanan masyarakat, yang disebabkan karena adanya ketidaksiapan masyarakat akan kondisi pandemi ini. Guncangan itu juga sangat dirasakan oleh salah satu sektor pekerjaan informal, yaitu Pedagang Kaki Lima (PKL). Hadirnya pandemi covid-19 membawa tantangan-tantangan baru dalam berdagang, hal itu menyebabkan kebertahanan mereka sebagai pedagang kaki lima menjadi goyah, adapun tantangan tersebut, diantaranya:

Pertama, dikeluarkannya kebijakan Pembatasan Sosial Berskala Besar (PSBB). Yang membuat aktivitas masyarakat sangat dibatasi jika diluar rumah, karena dihimbau untuk stay at home. Dengan adanya kebijakan tersebut, akan berdampak pada lainnya (1) Hilangnya pembeli dan pelanggan, karena ketika kebijakan itu dikeluarkan, masyarakat lebih memilih untuk tetap di rumah dan enggan untuk keluar rumah jika tidak penting.

"Kalau orang-orang ga keluar rumah kan jadinya sepi, kalau sepi gini pembelinya siapa” (Wawancara dengan Informan Ahmad, 19 April 2021).

(2) Menurunnya pendapatan, ini merupakan dampak lanjutan ketika pembeli berkurang, karena secara otomatis itu pun akan mengurangi pendapatannya juga. Penurunan pendapatan terjadi 50\% - 70\% dari pendapatan yang biasanya.

"Penghasilan sekarang mah hancur neng, berkurang, biasanya kan normalnya 700.000, 800.000, sekarang mah paling 250.000 atau 200.000, ngantonginnya 
paling 100.000, karena 100.000 laginya muter modal, syukur-syukur masih cukup buat makan" (Wawancara dengan Informan Fauzi, 1 April 2021).

Kedua, tantangan dari sisi kesehatan. Lebih khususnya dalam penerapan protokol kesehatan di masa pandemi covid-19 agar tubuh bisa tetap sehat dan terhindar dari virus covid-19. Saat ini negara Indonesia telah menerapkan kehidupan baru, atau new normal. Dalam kondisi tersebut terdapat protokol kesehatan yang harus diterapkan ketika berkegiatan di luar rumah, dikenal dengan 3M (Menggunakan masker, Mencuci tangan atau menggunakan hand sanitizer, dan Menjaga jarak).

"Tantangannya itu dari kesehatan, kita harus jaga kebersihan, jaga protokol kesehatan, kalau lagi covid gini. Soalnya kan kita gatau costumer kita memandang cara berdagang kita kaya gimana, kalau menerapkan protokol kan bisa mempengaruhi minat pembeli juga" (Wawancara dengan Informan Andrew, 19 April 2021).

Menjadi pedagang kaki lima merupakan pekerjaan yang masih mengharuskan mereka untuk keluar rumah, dan bertemu dengan orang-orang, maka dari itu penerapan akan protokol kesehatan haruslah ditingkatkan, agar cluster covid-19 di Indonesia tidak lagi bertambah. Apalagi pada bulan ramadhan, terjadinya peningkatan jumlah pedagang kaki lima di Pasar Lama, mereka menawarkan berbagai jenis takjil sebagai menu buka puasa, hal itu menyebabkan jumlah pembeli pun meningkat. Dengan kondisi yang seperti itu penerapan akan protokol kesehatan akan semakin sulit, terutama menjaga jarak.

Penerapan protokol kesehatan dianggap sebagai tantangan dikarenakan kurangnya kesadaran dari diri pedagang kaki lima akan pentingnya protokol kesehatan, dan akan bahayanya virus covid-19. Bahkan para pedagang kaki lima yang tergolong pada usia lanjut, menganggap bahwa virus covid-19 sebenarnya tidak ada di muka bumi, itu hanyalah sekedar isu yang sengaja dibuat untuk menggemparkan masyarakat.

Terdapat beberapa tantangan berdagang yang muncul pada masa pandemi covid19 ini, tapi mengapa para pedagang kaki lima masih tetap terlihat di pusat-pusat kota, terutama di Pasar Lama Kota Serang. Hal itu disebabkan karena: Pertama, Semangat berjualan para pedagang kaki lima, hal ini dilandasi demi terpenuhinya kebutuhan sehari-hari. Tidak bisa dielakkan bahwa manusia hidup memerlukan sandang, pangan, dan papan. Dalam realitanya, tidak peduli sesulit apa masyarakat untuk mendapatkan uang di masa pandemi ini, namun tetap saja harga kebutuhan-kebutuhan tersebut 
semakin hari semakin meningkat, bukan menurun. Dengan keadaan ini jika bukan dari diri kita sendiri yang berusaha, maka kehidupan kita ada diujung tanduk.

"Modal pernah sampe abis-abisan, tapi tetap berjuang ajalah, sekarang mah disabarin aja, mau susah atau seneng, demi anak dan istri yang penting bisa makan" (Wawancara dengan Informan Fauzi, 1 April 2021).

Kedua, culture pembeli, dikarenakan masyarakat Indonesia lebih mayoritas menempati posisi ekonomi menengah kebawah, dibandingkan menengah keatas. Pedagang kaki lima dianggap sebagai pedagang yang menawarkan barang dagangan dengan harga miring dan lebih murah dibandingkan dengan pedagang toko, walaupun biasanya memang kualitas barang dagangan yang ditawarkan relatif rendah. Hal ini tentu menjadi alasan terkuat mengapa banyak masyarakat Indonesia sebagai pembeli akan tertarik berbelanja di Pedagang Kaki Lima (PKL). Hal itu juga merupakan salah satu karakteristik pedagang kaki lima bahwa kualitas barang yang dijual relatif rendah, bahkan ada yang khusus menjual barang-barang dengan kondisi sedikit cacat dengan harga yang lebih murah lagi (Widodo dalam Jamaludin, 2017: 274). Keberadaan pedagang kaki lima pun dianggap sangat membantu dalam pemenuhan kebutuhan sehari-hari masyarakat.

"Sering banget belanja di pedagang kaki lima, karena pkl itu kan biasanya menjual barang-barang lebih murah gitu dibandingkan toko-toko, apalagi mall, sesuai lah dengan kantong-kantong orang menengah kebawah mah, ya walaupun kualitasnya emang lebih bagus di sana (toko-toko atau mall)" (Wawancara dengan Informan Eri, 4 April 2021).

Ketiga, adanya modal sosial. Konsep dalam modal sosial hadir karena adanya pemikiran bahwa anggota masyarakat tidak bisa menyelesaikan berbagai permasalahan secara individu, diperlukan kerjasama antar berbagai pihak yang terlibat didalam masyarakat tersebut (Syahra, 2003). Dengan adanya modal sosial ini, membuat masyarakat mudah dalam menyelesaikan permasalahan. Menurut Hasbullah (2006) modal sosial akan memfokuskan pada pembahasan mengenai potensi yang dimiliki kelompok melalui relasi-relasi sosial, dengan adanya pola hubungan antar individu dan kelompok, dengan memperhatikan jaringan sosial, norma, nilai, kepercayaan antar sesama yang lahir dari anggota kelompok dan menjadi norma kelompok.

Begitupun dengan pedagang kaki lima di Pasar Lama, pola hubungan melalui interaksi yang terjalin antar sesama pedagang, maupun pedangan dengan pembeli, terjalin dengan baik. Antar pedagang saling kenal dan sering mengadakan perbincangan 
mengenai bagaimana kondisi berdagang, misalnya penghasilan, kesulitan berdagang, sampai ke tahap pembicaraan penemuan solusi ketika terdapat hambatan dalam berdagang. Begitupun ketika akan terjadinya penertiban, para pedagang kaki lima di Pasar Lama saling memberi info dan saling mengingatkan kepada pedagang lainnya untuk membersihkan tempat tersebut dari lapak mereka berdagang, agar tidak ada pedagang yang terjaring razia.

Hubungan yang terjalin antara pedagang dan masyarakat pun terjalin dengan baik, masyarakat ini difokuskan pada pembeli. Karena menurut Damsar (2005) terdapat 3 tipe pembeli: (1) Pengunjung, adalah mereka yang datang ke lokasi pasar, tanpa tujuan untuk membeli suatu barang atau jasa, karena mereka adalah orang-orang yang menghabiskan waktu luang di lokasi pasar. (2) Pembeli, adalah mereka yang datang ke lokasi pasar dengan tujuan untuk membeli barang atau jasa, tetapi mereka tidak mempunyai tujuan akan ke pedagang yang mana untuk membelinya. (3) Pelanggan, adalah mereka yang datang ke lokasi pasar dengan maksud untuk membeli barang atau jasa, dan sudah memiliki tujuan akan membeli di pedagang mana. Maka dari itu difokuskan pada bagaimana hubungan antara pedagang dan pembeli, dan ternyata pembeli memberikan respon positif dengan adanya pedagang kaki lima di Pasar Lama, karena dapat memenuhi kebutuhan pangan pembeli dengan harga yang terjangkau, selain itu juga pedagang kaki lima di Pasar Lama dinilai tidak terlalu menimbulkan permasalahan, karena para pedagang menjaga kebersihan tempat di sekitar lapak, namun terdapat juga permasalahan yang tidak bisa dihindarkan dari adanya pedagang kaki lima di Pasar Lama, yaitu kemacetan.

Gambar 3. Kemacetan yang Disebabkan Karena Adanya PKL di Bahu Jalan

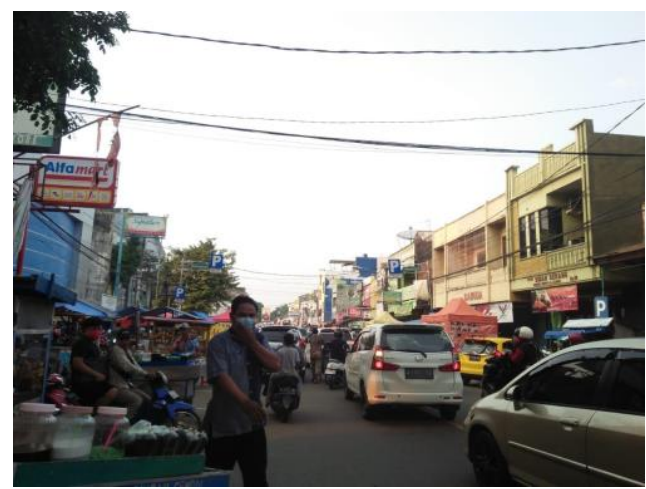

Sumber : Dokumentasi Peneliti, 2021 
Tiga hal diatas yang telah dipaparkan merupakan jawaban yang membuat para pedagang kaki lima masih tetap bertahan selama bertahun-tahun, bahkan sampai saat ini ketika pandemi covid-19 menyerang negara Indonesia, dengan membawa berbagai dampak dan tantangan baru dalam berdagang. Dapat ditarik simpulan mereka mampu bertahan karena adanya kesesuaian antara pedagang dan pembeli, ketika pedagang memiliki semangat yang membara untuk tetap berdagang, para pembeli pun merespon positif akan keberadaan pedagang kaki lima, karena dianggap sangat membantu pembeli untuk pemenuhan kebutuhan mereka.

\section{KESIMPULAN}

Pedagang Kaki Lima (PKL) merupakan orang yang berada pada golongan ekonomi menengah kebawah, yang memiliki usaha namun pada tempat yang tidak seharusnya, misalnya di bahu jalan, trotoar, ataupun taman kota. Keberadaan pkl di tengah kota sangatlah terancam, hal itu karena 1) Terdapat Peraturan Daerah (PERDA) Kota Serang No. 10 Tahun 2010, tentang Ketertiban, Kebersihan, dan Keindahan (K3) dan Peraturan daerah No 4 Tahun 2014. Yang membahas mengenai: beberapa tempat yang diizinkan untuk melakukan usaha oleh pedagang kaki lima, mekanisme penertiban dan penyitaan, penataan, pemberdayaan pedagang kaki lima, sampai dengan sanksi dan denda jika ada pelanggaran. Dikeluarkannya kebijakan itu akan bermuara pada relokasi PKL di Pasar Lama ke tempat yang telah disediakan yaitu Pasar Kepandean, namun para pedagang enggan dan menolak untuk direlokasi. 2) Terdapat tantangan baru saat berdagang di masa pandemi ini diantaranya: Kebijakan PSBB, dan Tantangan kesehatan. Yang membawa beberapa dampak baru dalam berdagang: berkurangnya pembeli, dan menurunnya pendapatan. Namun, walaupun terdapat kebijakan, tantangan, dan dampak yang dirasakan oleh pedagang kaki lima di masa pandemi ini, mereka masih tetap bertahan, hal itu dikarenakan (1) adanya semangat berdagang para pedagang (2) culture pembeli yang sangat minat berbelanja di pedagang kaki lima (3) modal sosial yang baik antar pedagang maupun dengan pembeli.

Berdasarkan kajian Sosiologi Perkotaan Pedagang Kaki Lima (PKL) merupakan salah satu dari sekian banyak permasalahan di perkotaan. Hal ini perlu diatasi agar pedagang kaki lima semakin hari tidak semakin liar dan menyebar pada pusat dan sudut-sudut perkotaan. Penelitian ini berusaha memberikan kontribusi dalam mengatasi 
permasalahan tersebut, sebagai rekomendasi untuk pemangku kebijakan dan dinas terkait, perlu kiranya untuk membuat model pemberdayaan pedagang kaki lima, yang sesuai dengan kebutuhan dan kondisi mereka. Dengan cara melibatkan suara para pedagang kaki lima, atau paling tidak perwakilan dari pihak pedagang kaki lima pada tahap penentuan maupun perumusan kebijakan. Agar nantinya kebijakan yang ditetapkan dapat sesuai dengan seluruh komponen masyarakat, tidak terkecuali pedagang kaki lima itu sendiri. Karena pemberdayaan yang sesuai akan memunculkan dampak yang maksimal untuk mengatasi permasalah perkotaan ini. Pedagang kaki lima memang termasuk permasalahan di kota, namun jika mampu dan berhasil dipemberdayakan hal itu akan menjadi aset ekonomi bangsa dalam menekan angka pengangguran.

\section{DAFTAR PUSTAKA}

Andriani, R., \& Marlina, L. 2020. "Peran Satuan Polisi Pamong Praja Dalam Meningkatkan Ketertiban Pedagang Kaki Lima". Pro Patria: Jurnal Pendidikan, Kewarganegaraan, Hukum, Sosial, dan Politik, 3(2). https://doi.org/10.47080/propatria.v3i2.984

Damsar. 2005. Sosiologi Pasar. Padang: Laboratorium Fisip Universitas Andalas.

Hasbullah. 2006. Sosial Capital: Menuju Keunggulan Budaya Manusia Indonesia. Jakarta: MR. United Press Jakarta.

Jamaludin, Adon Nasrullah. 2017. Sosiologi Perkotaan: Memahami Masyarakat Kota dan Problemanya. Bandung: Pustaka Setia.

Musahwi, Stevany Afrizal, S. J. 2018. "Jaringan Sosial dan Pemberdayaan Pedagang Perempuan di Pasar Tradisional Rau Kota Serang". Jurnal Hermeneutika, 4(2). https://jurnal.untirta.ac.id/index.php/Hermeneutika

Peraturan Pemerintah Daerah Kota Serang Nomor 10 Tahun 2010. Tentang Ketertiban, Kebersihan, dan Keindahan. https://jdih.serangkota.go.id/berdasarkan/peratur andaerah/10/2010/ketertiban.

Peraturan Pemerintah Daerah Kota Serang Nomor 4 Tahun 2014. Tentang Penataan dan Pemberdayaan Pedagang Kaki Lima. https://jdih.serangkota.go.id/cari/penataandan-pemberdayaan-pedagang kaki-lima.

Satpol PP Kota Serang. 2020. Penertiban PKL Pasar Lama. (Online). https://satpolpp.serangkota.go.id/detailpost/penertiban-pkl-pasar-lama. (diakses pada 27 April 2020) 
Sugiyono. 2010. Metode Penelitian Pendidikan: Pendekatan Kuantitatif, Kualitatif, dan $R \& D$. Bandung: Alfabeta.

Syahra, R. 2003. "Modal sosial: Konsep dan aplikasi". Jurnal Masyarakat dan Budaya, 5(1). http://www.jurnalmasyarakatdanbudaya.com/index.php/jmb/ article/view/256 